\title{
UJI AKTIVITAS PENYUBUR RAMBUT KOMBINASI EKSTRAK AIR TEH HIJAU DAN HERBA PEGAGAN
}

\section{HAIR GROWTH ACTIVITY TEST OF COMBINATION OF GREEN TEA AND GOTUKOLA HERB WATER EXTRACT}

\author{
Lela Sulastri ${ }^{1}$, Teti Indrawati ${ }^{2}$, Shelly Taurhesia ${ }^{2}$ \\ ${ }^{1}$ Akademi Farmasi Muhammadiyah Cirebon \\ Jl. Cideng Indah no. 3 Cirebon \\ ${ }^{2}$ Fakultas Farmasi Universitas Pancasila \\ Srengseh Sawah, Jagakarsa, Jakarta \\ Email: lelasulastri79@yahoo.co.id
}

Submitted: 03-12-2015

Reviewed: 22-02-2016

Accepted: 24-04-2016

\begin{abstract}
ABSTRAK
Sediaan penyubur rambut digunakan untuk menstimulus pertumbuhan rambut yang digunakan dengan dioleskan pada kulit kepala. Bahan alam yang diperkirakan dapat digunakan sebagai penyubur rambut adalah daun teh hijau dan herba pegagan. Daun teh hijau mengandung zat kimia polifenol yaitu flavonoid beserta turunannya dan herba pegagan dengan kandungan senyawa utama triterpenoid saponin yaitu asiatikoside, flavonoid, fitosterol, madecassid acid, madecassoside, asam asiatik dan asam amino yang diduga mempunyai khasiat sebagai penyubur rambut. Penelitian ini dilakukan untuk mengetahui apakah kombinasi ekstrak air daun teh hijau dan herba pegagan mempunyai aktivitas sebagai penyubur rambut dan kombinasi manakah yang memiliki aktivitas paling optimum. Uji aktivitas penyubur rambut meliputi laju pertumbuhan rambut, percepatan pertumbuhan rambut dan bobot rambut. Pada penelitian ini digunakan 3 kombinasi yaitu kombinasi 1 (ekstrak air daun teh hijau 5\% dan ekstrak air herba pegagan 2,5\%), kombinasi 2 (ekstrak air daun teh hijau 7,5\% dan ekstrak air herba pegagan 2,5\%) dan kombinasi 3 (ekstrak air daun teh hijau 5\% dan ekstrak air herba pegagan 7,5\%). Hasil penelitian menunjukkan kombinasi ekstrak air daun teh hijau dan ekstrak air herba pegagan mempunyai aktivitas sebagai penyubur rambut dan kombinasi ekstrak yang paling optimum adalah kombinasi 1 dengan konsentrasi ekstrak air daun teh hijau (5\%) dan ekstrak air herba pegagan (2,5\%) dengan laju pertumbuhan rambut $2,689 \mathrm{~cm}$ dalam 28 hari, percepatan pertumbuhan rambut $0,128 \mathrm{~cm} / \mathrm{hari}$ dan bobot rambut 0,1938 gram dalam 28 hari.
\end{abstract}

Kata kunci: penyubur rambut, teh hijau, pegagan

\begin{abstract}
Hair fertilizer was used to stimulate hair growth that is used topically on the scalp. Natural materials are expected to be used as fertilizer hair is green tea leaves and herb gotukola. Because the green tea leaves contain a chemical polyphenol compounds that are flavonoids and their derivatives and herb gotukola contain lead compound triterfenoid saponin that are asiatikoside, flavonoids, phytosterols, madecassid acid, madecassoside, asiatic acid and amino acids are thought to have properties as fertilizer hair. This study was conduced to determine whether the combination of the water extract of green tea leaves and herb gotukola has activity as a hair fertilizer and combination which has the most optimum activity. Test hair fertilizer activities include the rate of hair growth, hair growth acceleration and the weight of the hair. In this study used three combinations are combination 1 ( the water extract of green tea leaves and 5\% water gotukola herb extract $2.5 \%$ ), combination 2 (the water extract of green tea leaf extract $7.5 \%$ and $2.5 \%$ water gotukola herb) and combination 3 (the water extract of green tea leaves and
\end{abstract}


$5 \%$ water gotukola herb extract $7.5 \%$ ). The results showed the combination of the water extract of green tea leaves and water extract herb gotukola has activity as fertilizer hair and extract the most optimum combination is a combination of 1 with a concentration of water extract of green tea leaves (5\%) and water extract of the herb gotukola $(2.5 \%)$ the rate of hair growth $2.689 \mathrm{~cm}$ in 28 days, accelerated hair growth $0.128 \mathrm{~cm} /$ day and the hair weighs 0.1938 grams in 28 days.

Keywords: hair growth, green tea, gotukola

\section{PENDAHULUAN}

Rambut merupakan bagian yang keluar dari dalam kulit dan kulit kepala, yang memiliki fungsi dasar sebagai pelindung, organ sensori, menjaga kestabilan suhu tubuh dan sebagai pertanda status sosial. Rambut mengalami proses pertumbuhan menjadi dewasa dan bertambah panjang lalu rontok dan kemudian terjadi pergantian rambut baru. Kondisi fisiologis,stress emosional maupun fisik, nutrisi, gangguan hormonal dan obat dapat mempengaruhi pertumbuhan rambut yang dapat menstimulasi terjadinya gangguan pada rambut berupa rambut yang tipis, mudah patah, berkurangnya pigmen rambut, kerontokan bahkan kebotakan (Harrison 2009). Sekarang banyak sediaan penyubur rambut yang digunakan untuk menstimulus pertumbuhan rambut yang digunakan dengan dioleskan pada kulit kepala. Sediaan tersebut mengandung sejumlah bahan aktif berupa bahan kimia misalnya minoxidil maupun bahan alam diantaranya lidah buaya, bunga sepatu,gingseng, ginkgo biloba, pegagan dan teh hijau (Thorat 2010).

Teh hijau mengandung senyawa polifenol yaitu flavonoid beserta turunanannya yaitu flavanol, flavandiol dan asam fenolat. Adapun polifenol terbesar pada teh hijau adalah flavanol dengan komponen mayor epikatekin (EC), epikatekin galat (ECG), epigalokatekin galat (EGCG), galokatekin galat (GCG), galokatekin (GC), katekin galat (CG), katekin (C) (Sandeep 2012). Ekstrak etanol daun teh hijau 2,5\% berdasarkan hasil penelitian Amin (2014) pada tikus jantan putih mempunyai aktivitas sebagai penyubur rambut yang optimal. Penelitian lain menjelaskan bahwa $33 \%$ tikus jantan yang mengalami kebotakan yang diberi minum 50\% fraksi polifenol yang berasal dari teh hijau selama 60 hari menunjukkan pertumbuhan rambut yang memiliki perbedaan signifikan dibandingkan kelompok tikus yang hanya diberikan minum aquadest (Esfandiari 2005). Longo (2007) melakukan penelitian efek epigalokatekin galat (EGCG) yang berasal dari teh hijau pada folikel rambut dan sel-sel dermal papilla yang dibudidayakan menunjukkan kultur folikel rambut mengalami peningkatan elongasi dan pertumbuhan rambut dan sel dermal papilla mengalami proliferasi yang lebih kuat dibandingkan dengan kontrol.

Pegagan (Centella asiatica (L) Urban) dengan kandungan senyawa utama triterfenoid saponin yaitu asiatikoside, flavonoid, fitosterol, madecassid acid, madecassoside, asam asiatik,asam amino, asam lemak, steroid, tanin, alkaloid merupakan salah satu tumbuhan yang dapat digunakan dalam perawatan rambut rontok termasuk pada kebotakan laki-laki ( Thorat 2010; Zheng 2006). Kaitannya sebagai penyubur rambut, dijelaskan dalam penelitian bahwa ekstrak etanol pegagan 4 bagian telah dikombinasikan dengan Citrus limonis (2 bagian), Cuscuta reflexa (10 bagian), Emblica officinalis (4 bagian), Allium cepa (5 bagian), Lawsonia inermis (2 bagian), Azadirachta indica (5 bagian), Eclipta alba (5 bagian), Ocimum sanctum (3bagian) dan Eugenia caryophyllus (4 bagian) yang difomulasikan dalam bentuk sediaan salep yang diaplikasikan secara topikal pada tikus selama 28 hari menunjukkan adanya aktivitas pertumbuhan rambut (Sharma 2010). Selain itu ekstrak pegagan $5 \% \mathrm{~b} / \mathrm{b}$ tunggal maupun yang dikombinasikan dengan ekstrak Emblica officinalis $5 \% \mathrm{~b} / \mathrm{b}$, ekstrak Aloe vera $5 \% \mathrm{~b} / \mathrm{b}$, ekstrak, Ocimum sanctum 5\% b/b, ekstrak Eclipta alba $5 \%$ b/b. dalam sediaan salep yang diaplikasikan secara topikal pada tikus menunjukkan aktivitas sebagai penyubur rambut (Jain 2011).

Pegagan dan teh hijau merupakan jenis tumbuhan yang mudah diperoleh dan sudah sering digunakan secara empiris dalam kehidupan sehari-hari untuk berbagai khasiat. Kaitannya sebagai penyubur rambut dari masing-masing tumbuhan tersebut sudah ditunjukkan dengan adanya berbagai penelitian. Berdasarkan penelitian Purwanti (2008) bahwa kombinasi ekstrak daun teh dan ekstrak daun mangkokan mempunyai aktivitas mempercepat pertumbuhan rambut lebih baik daripada ekstrak sediaan tunggal. Perbedaan dengan penelitian ini adalah ekstrak air daun teh hijau dikombinasikan dengan ekstrak air herba pegagan. Pada penelitian ini dilakukan uji aktivitas penyubur rambut kombinasi dari ekstrak air daun teh hijau dan herba pegagan dalam tiga (3) kombinasi yaitu kombinasi 1 (ekstrak air 
daun teh hijau 5\% dan ekstrak air herba pegagan 2,5\%), kombinasi 2 (ekstrak air daun teh hijau 7,5\% dan ekstrak air herba pegagan 2,5\%) dan kombinasi 3 (ekstrak air daun teh hijau 5\% dan ekstrak air herba pegagan 7,5\%). Hasil penelitian ini diharapkan dapat diketahui apakah kombinasi ekstrak air daun teh hijau (Camelia sinensis (L.) O.K.) dan ekstrak air herba pegagan (Centella asiatica,(Linn),Urb.) mempunyai aktivitas sebagai penyubur rambut dan kombinasi manakah yang memberikan aktivitas paling optimum sebagai penyubur rambut. Uji aktivitas penyubur rambut meliputi laju pertumbuhan rambut, percepatan pertumbuhan rambut dan bobot rambut (Amin 2014; Priskila 2012; Purwantini 2008).

\section{METODE PENELITIAN}

Alat dan Bahan

Alat yang digunakan dalam penelitian ini antara lain : alat- alat gelas (labu ukur pyrex, erlemeyer pyrex, beker glas pyrex, gelas ukur pyrex), timbangan analitik (RADWAG ${ }^{\circledR}$ AS 160/C/2), gunting rambut, pinset, selotip, lakban dan jangka sorong. Bahan yang digunakan dalam penelitian ini adalah : Ekstrak air daun teh hijau (PT Java Plant), Ekstrak air herba pegagan (PT Java Plant), Etanol 70 $\%$ (PT Bratachem), Aquadest (CV Mustika Lab), Hair Tonic merk X dengan nomor Batch 187021 Exp. Juli 2016.

\section{Hewan Uji}

Hewan uji yang digunakan adalah kelinci putih jantan usia 3-4 bulan dengan bobot badan 2-3 kg dengan jumlah kelinci yang digunakan ditentukan dengan menggunakan rumus empiris Federer: (n-1) $(\mathrm{t}-1) \geq 15$, t menunjukkan jumlah perlakuan dan $\mathrm{n}$ menunjukkan jumlah hewan tiap perlakuan (Amin 2014; Priskila 2012; Purwantini 2008). Berdasarkan rumus empiris Federer maka jumlah hewan yang digunakan adalah 4 ekor kelinci putih jantan. Pada punggung masing-masing kelinci dibuat 6 daerah pengolesan yaitu kombinasi 1 , kombinasi 2, kombinasi 3, kontrol normal, kontrol negatif dan kontrol positif.

\section{Jalannya Penelitian \\ Pembuatan larutan kombinasi}

Pembuatan larutan kombinasi ekstrak air daun teh hijau dan ekstrak air herba pegagan dengan perbandingan $5 \%$ b/v: 2,5\% b/v (Kombinasi 1) ; 7,5\% b/v: 2,5\% b/v (Kombinasi 2) ; 5\% b/v: 7,5\% b/v (Kombinasi 3) dengan cara sebagai berikut :

a. Kombinasi 1 dibuat dengan cara melarutkan $5 \mathrm{~g}$ ekstrak air daun teh hijau dan 3,3 g ekstrak air herba pegagan hingga $100 \mathrm{ml}$ aquadest.

b. Kombinasi 2 dibuat dengan cara melarutkan 7,5 g ekstrak air daun teh hijau dan 3,3 g ekstrak air herba pegagan hingga $100 \mathrm{ml}$ aquadest.

c. Kombinasi 3 dibuat dengan cara melarutkan $5 \mathrm{~g}$ ekstrak air daun teh hijau dan $10 \mathrm{~g}$ ekstrak air herba pegagan hingga $100 \mathrm{ml}$ aquadest.

Keterangan : Dalam $1 \mathrm{~kg}$ ekstrak kering herba pegagan terdapat $75 \%$ ekstrak herba pegagan dan 25 $\%$ pengisi maltodekstrin.

\section{Persiapkan hewan uji setelah adaptasi.}

Setelah 1 (satu) minggu diadaptasikan, punggung kelinci dibersihkan dari rambut dengan cara dicukur hingga bersih, dibagi menjadi 6 bagian daerah pengolesan yang masing-masing berbentuk segi empat dengan luas area $2 \times 2,5 \mathrm{~cm}$ dan jarak antar daerah $1 \mathrm{~cm}$. Sebelum dilakukan pengolesan, punggung kelinci yang telah dicukur diolesi etanol $70 \%$ sebagai antiseptik. Daerah pengolesan pada punggung kelinci dapat dilihat pada Gambar 1 dan pada setiap kelinci dilakukan pengacakan daerah pengolesan. 


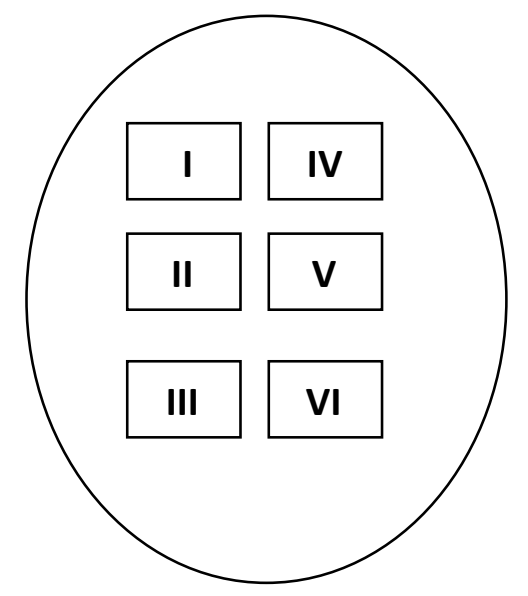

KELINCI 1

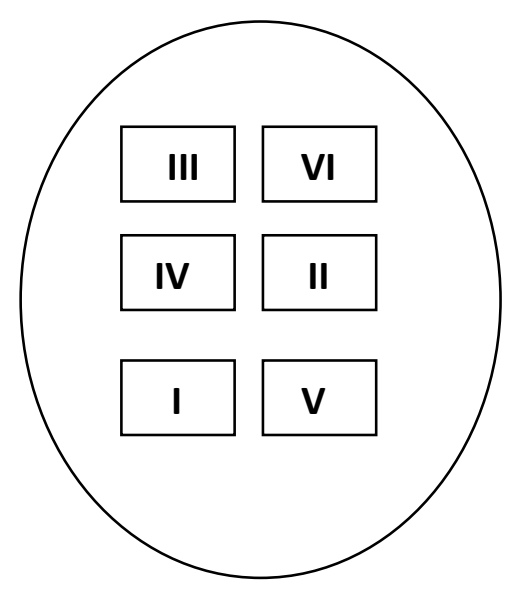

KELINCI 3

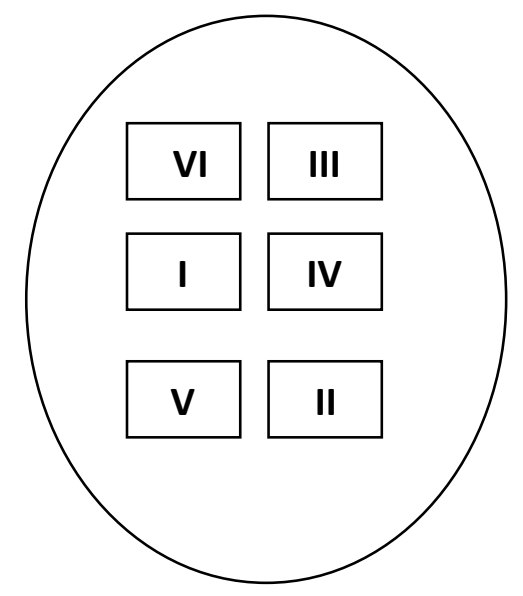

KELINCI 2

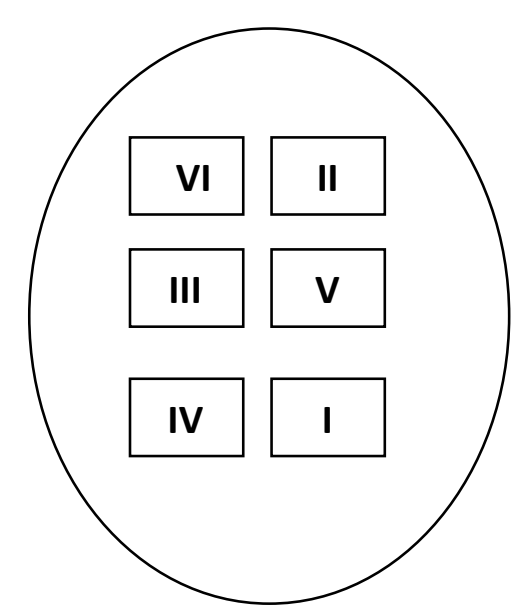

KELINCI 4

Gambar 1. Daerah pengolesan pada punggung kelinci

Keterangan:

Daerah I diolesi sediaan hair tonik yang ada dipasaran sebagai kontrol positif.

Daerah II diolesi aquadest sebagai kontrol negatif.

Daerah III tanpa diolesi apa-apa sebagai kontrol normal.

Daerah IV diolesi kombinasi 1.

Daerah V diolesi kombinasi 2.

Daerah VI diolesi kombinasi 3.

Uji aktivitas penyubur rambut kombinasi ekstrak air daun teh hijau (Camellia sinensis (L) OK) dan herba pegagan (Centella asiatica (L) Urban).

Uji aktivitas kombinasi ekstrak air daun teh hijau dan ekstrak air herba pegagan terhadap laju pertumbuhan rambut dilakukan dengan mengoleskan sediaan campuran ekstrak dilakukan tiap hari 2 kali yaitu pagi dan sore dengan berat masing-masing 1 gram pada masing-masing bagian. Hari pertama pengolesan dianggap hari ke -0. Pengamatan dilakukan selama 28 hari, dengan mengambil 6 helai 
rambut kelinci tiap 7 hari sekali, dihitung pada hari ke-7, ke-14, ke-21, dan ke-28. Rambut diambil dengan cara dipotong, diluruskan, dan ditempelkan pada solatip, kemudian diukur panjang rambut dengan menggunakan jangka sorong. Pada hari ke-28 dilakukan pencukuran rambut masing-masing area kemudian ditimbang bobot rambut. Pada setiap kelinci terdapat pengacakan daerah pengolesan.

\section{Analisis Data}

Uji aktivitas penyubur rambut meliputi laju pertumbuhan rambut dan bobot rambur. Laju pertumbuhan rambut diperoleh dari panjang rambut. Data panjang rambut dan bobot rambut yang diperoleh selanjutnya diolah secara statistik untuk melihat apakah ada perbedaan yang bermakna antara daerah uji dengan kontrol.Untuk melihat normalitas serta homogenitas data, dilakukan uji normalitas (Saphiro-Wilk) dan uji homogenitas (Levene). Distribusi data yang normal dan homogen diolah untuk uji analisis ragam atau analysis of variance (ANOVA). Tujuan dilakukan uji ANOVA adalah untuk mengetahui ada atau tidaknya perbedaan yang bermakna secara statistik dari kelompok perlakuan secara keseluruhan. Selanjutnya, untuk melihat perbedaan bermakna secara statistik antar kelompok uji, maka dilakukan uji beda nyata terkecil (BNT). Distribusi data yang tidak normal atau tidak homogen diolah menggunakan statistik nonparametik yaitu uji Kruskal Wallis. Kemudian dilanjutkan dengan uji MannWhitney untuk melihat adanya perbedaan bermakna pada masing-masing kelompok uji dengan tingkat kepercayaan sebesar 95\% (Amin, 2014).

\section{HASIL DAN PEMBAHASAN}

a. Laju pertumbuhan rambut kelinci yang diberi olesan kombinasi ekstrak air daun teh hijau dan herba pegagan dapat dilihat pada Tabel I

Tabel I. Laju pertumbuhan rambut kelinci yang diberi kombinasi ekstrak air daun teh hijau dan ekstrak air herba pegagan.

\begin{tabular}{llccc}
\hline \multirow{2}{*}{ Perlakuan } & \multicolumn{4}{c}{$\begin{array}{c}\text { Rata -rata panjang } \\
(\mathbf{c m}) \pm \text { SD }\end{array}$} \\
\cline { 2 - 5 } & Hari ke-7 & Hari ke-14 & Hari ke-21 & Hari ke -28 \\
\hline Kontrol Normal & $0,501 \pm 0,05$ & $0,729 \pm 0,03$ & $1,105 \pm 0,22$ & $1,483 \pm 0,38$ \\
Kontrol Negatif & $0,598 \pm 0,03$ & $0,932 \pm 0,05$ & $1,358 \pm 0,26$ & $1,729 \pm 0,40$ \\
Kontrol Positif & $0,732 \pm 0,02$ & $1,453 \pm 0,46$ & $1,839 \pm 0,42$ & $2,376 \pm 0,39$ \\
Kombinasi 1 & $0,897 \pm 0,29$ & $1,647 \pm 0,30$ & $2,140 \pm 0,39$ & $2,689 \pm 0,39$ \\
Kombinasi 2 & $0,793 \pm 0,14$ & $1,543 \pm 0,16$ & $1,908 \pm 0,15$ & $2,565 \pm 0,38$ \\
Kombinasi 3 & $0,687 \pm 0,04$ & $1,402 \pm 0,41$ & $1,768 \pm 0,71$ & $2,316 \pm 0,46$ \\
\hline
\end{tabular}

Hasil uji aktivitas penyubur rambut terlihat bahwa pada hari ke-7 sudah menunjukkan adanya pertumbuhan rambut yang ditandai dengan bertambah panjang rambut. Panjang rambut mengalami pertambahan panjang setiap minggunya pada semua perlakuan. Dari Tabel I terlihat bahwa kontrol normal yang tidak menerima perlakuan menggambarkan pertumbuhan yang normal, dimana pertumbuhannya lebih lambat dibandingkan kombinasi 1,2,3 dan kontrol positif tetapi tetap setiap minggunya mengalami pertambahan panjang rambut. Demikian halnya dengan kontrol negatif terlihat juga mengalami pertumbuhan yang lebih lambat dan mengalami pertambahan panjang setiap minggunya. Kombinasi $1(2,689 \pm 0,39)$ terlihat pada hari ke-28 mempunyai panjang rambut yang lebih panjang dibandingkan dengan kombinasi $2(2,565 \pm 0,38)$ dan kombinasi $3(2,316 \pm 0,46)$.

Rata-rata panjang sampai hari ke-28 menunjukkan data terdistribusi normal dan homogen sehingga analisa statistik menggunakan uji Anava yang menunjukkan adanya perbedaan bermakna dan dilanjutkan dengan uji beda nyata terkecil (BNT). Hasil uji ini menunjukkan terdapat perbedaan bermakna pada kontrol normal dibandingkan dengan kombinasi 1, kombinasi 2 , kombinasi $3(\mathrm{p}<0,05)$, hal ini menunjukkan adanya pertumbuhan rambut yang signifikan secara statistik pada ketiga kombinasi pada hari ke-28 bila dibandingkan dengan kontrol normal. Namun, perbandingan statistik tidak menunjukkan perbedaan bermakna $(\mathrm{p}>0,05)$ pada rata-rata panjang rambut antar kombinasi dengan 
kontrol positif pada hari ke-28. Hal ini menunjukkan bahwa semua kombinasi pada hari ke-28 memiliki aktivitas pertumbuhan rambut yang sama efektif dibandingkan dengan kontrol positif. Pada perbandingan antara masing-masing kombinasi I, kombinasi II, serta kombinasi III untuk melihat kombinasi yang paling efektif hingga hari ke-28, hasil pengolahan data menyatakan masih tidak terdapat perbedaan secara bermakna ( $>00,05)$ antar kombinasi. Dengan kata lain, kombinasi I dengan konsentrasi ekstrak teh hijau terkecil (5\%) dan ekstrak pegagan terkecil (2,5\%) merupakan kombinasi yang paling efektif hingga hari ke-28.

b. Percepatan pertumbuhan rambut

Tabel II. Percepatan pertumbuhan rambut kelinci yang diberi kombinasi ekstrak air daun teh hijau dan ekstrak air herba pegagan

\begin{tabular}{lccccc}
\hline \multirow{2}{*}{ Perlakuan } & \multicolumn{5}{c}{ Percepatan pertumbuhan rambut( cm/hari) } \\
\cline { 2 - 6 } & Hari ke-0 & Hari ke-7 & Hari ke-14 & Hari ke-21 & Hari ke-28 \\
\hline Kombinasi 1 & 0 & 0,128 & 0,118 & 0,102 & 0,096 \\
Kombinasi 2 & 0 & 0,113 & 0,110 & 0,091 & 0,092 \\
Kombinasi 3 & 0 & 0,098 & 0,100 & 0,084 & 0,083 \\
Kontrol Positif & 0 & 0,105 & 0,104 & 0,088 & 0,085 \\
Kontrol Negatif & 0 & 0,085 & 0,067 & 0,065 & 0,062 \\
Kontrol Normal & 0 & 0,072 & 0,052 & 0,053 & 0,053 \\
\hline
\end{tabular}

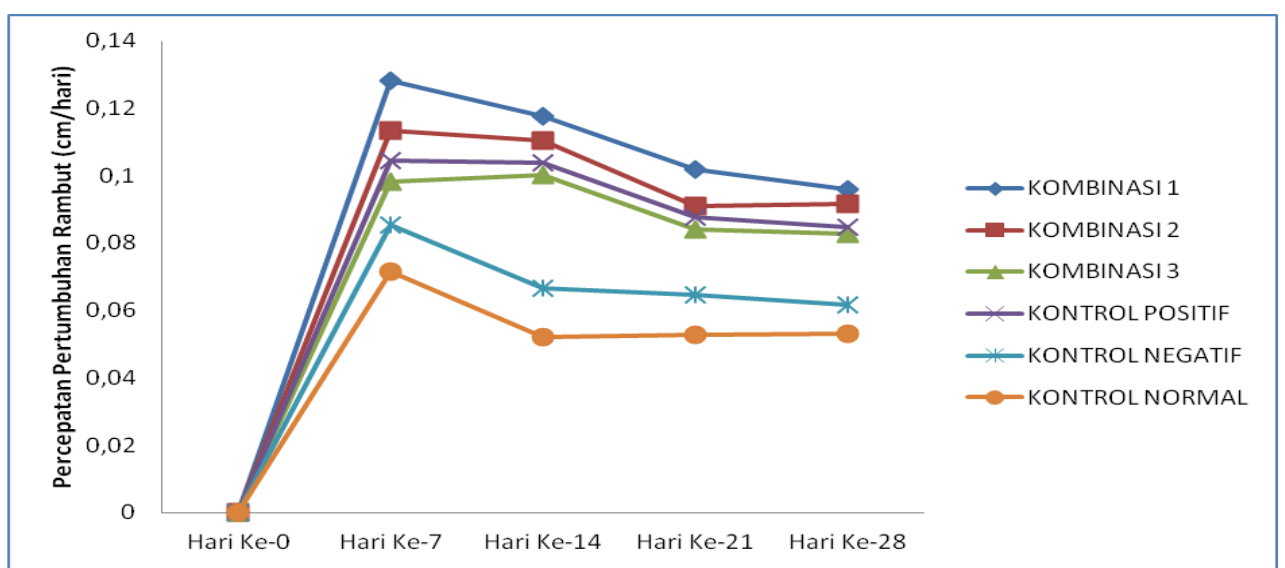

Gambar 2. Grafik percepatan pertumbuhan rambut kelinci pada kombinasi ekstrak dibandingkan dengan kontrol normal, kontrol positif dan kontrol negatif

Berdasarkan Gambar 2 tersebut diatas terlihat bahwa percepatan pertumbuhan rambut yang paling cepat pada kontrol normal, kontrol positif, kontrol negatif maupun kombinasi semuanya terjadi pada hari yang sama yaitu hari ke-7 dimana percepatan pertumbuhan rambut yang dimiliki kombinasi 1 $(0,128 \mathrm{~cm} /$ hari $)$ lebih cepat daripada kombinasi $2(0,113 \mathrm{~cm} /$ hari $)$, kombinasi $3(0,098 \mathrm{~cm} / \mathrm{hari})$ kontrol positif $(0,105 \mathrm{~cm} /$ hari), kontrol negatif $(0,085)$ dan kontrol normal $(0,072 \mathrm{~cm} /$ hari $)$. Pada hari ke-14 terlihat mengalami penurunan percepatan pertumbuhan rambut, dimana kontrol normal dan kontrol negatif hari ke- 14 mengalami penurunan yang tajam dan hari ke-21 sampai dengan ke-28 mempunyai percepatan pertumbuhan yang tetap. Kombinasi 1, kombinasi 2, 3 dan kontrol positif pada hari ke-14 sampai dengan hari ke- 28 mengalami penurunan percepatan pertumbuhan rambut secara perlahan-lahan dimana kontrol positif mempunyai percepatan pertumbuhan rambut yang lebih cepat daripada kombinasi 3. Dengan demikian maka kombinasi ekstrak air teh hijau dan pegagan dibandingkan dengan kontrol normal, kontrol positif dan negatif mempunyai percepatan pertumbuhan rambut tercepat yang terjadi pada hari yang sama (hari ke-7) dengan pola yang sama dan nilai tertinggi adalah kombinasi 1. 
c. Bobot rambut

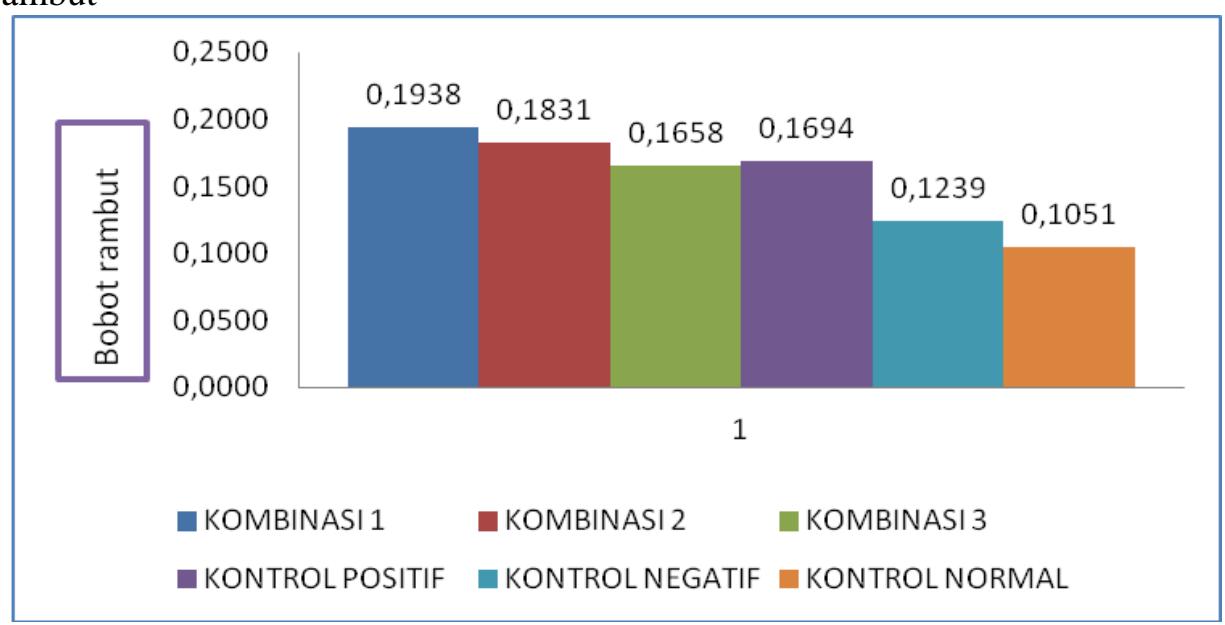

Gambar 3. Diagram batang bobot rambut kelinci yang diberi kombinasi ekstrak air daun teh hijau dan ekstrak air herba pegagan

Hasil penelitian menunjukkan bahwa semua kombinasi ekstrak teh hijau dan ekstrak air herba pegagan dapat menambah ketebalan rambut, dimana kombinasi 1 menghasilkan bobot rambut yang lebih besar dibandingkan dengan perlakuan lainnya. Bobot rambut yang besar menggambarkan diameter/ketebalan rambut yang besar pula. Dari gambar juga terlihat kontrol normal mempunyai bobot rambut yang lebih kecil, menggambarkan ketebalan yang dihasilkan dari pertumbuhan normal. Kontrol negatif menghasilkan bobot rambut yang masih dibawah kombinasi ketiga ekstrak dan kontrol positif.

Data rata-rata bobot rambut terdistribusi normal tidak homogen sehingga analisa statistik menggunakan uji Kruskal Wallis dan dilanjutkan uji Mann Whitney. Hasil analisa statistik menunjukkan adanya perbedaan yang bermakna pada kontrol normal dan kontrol negatif jika dibandingkan dengan kombinasi 1, kombinasi 2, kombinasi 3, dan kontrol positif dan antara kombinasi 1, kombinasi 2 dan kombinasi 3 tidak ada perbedaan yang bermakna jika dibandingkan dengan kontrol positif $(\mathrm{p}<0,05)$. Hal ini menunjukkan bahwa ketiga kombinasi ekstrak tersebut mempunyai aktivitas sebagai penyubur rambut (tebal rambut) yang sama baiknya dengan kontrol positif. Berdasarkan data tersebut dapat dilihat bahwa kombinasi 1 (ekstrak teh hijau 5\% dan ekstrak pegagan 2,5\%) merupakan kombinasi yang optimal karena mempunyai bobot rambut yang paling berat $(0,1938$ gram) yang menghasilkan rambut paling tebal pada hari ke-28.

Berdasarkan hasil penelitian maka ke-3 kombinasi tersebut mempunyai aktivitas sebagai penyubur rambut dan yang paling optimum adalah kombinasi 1 dengan konsentrasi ekstrak air daun teh hijau $(5 \%)$ dan ekstrak air herba pegagan $(2,5 \%)$ dengan laju pertumbuhan rambut 2,689 cm dalam 28 hari, percepatan pertumbuhan rambut $0,128 \mathrm{~cm} /$ hari dan bobot rambut 0,1938 gram dalam 28 hari. Kombinasi 1 dibandingkan dengan kombinasi 2 dan 3 tujuannya adalah untuk menentukan kombinasi mana yang paling optimum sebagai penyubur rambut karena pada ketiga kombinasi tersebut mempunyai kadar zat aktif yang berbeda-beda.

Aktivitas penyubur rambut dari kombinasi tersebut pada teh hijau diperkirakan karena adanya kandungan polifenol dengan mekanisme kerja menstimulasi dan meningkatkan proliferasi sel pada sel papilla dermal rambut, menekan produksi Tumor Necrosis Factor - alpha (TNF alpha) yang memicu terjadinya kebotakan dan adanya adanya asam galat, vitamin $\mathrm{B}$ dan $\mathrm{C}$ mampu memperkuat akar rambut, mencegah kerontokan, menghambat radikal bebas, menetralkan racun, dan ,melindungi kulit kepala dari infeksi ( Jain 2011; Sandeep 2012; Esfandiari 2005).

Aktivitas penyubur rambut dari herba pegagan diperkirakan karena kandungan flavonoid dengan mekanisme merangsang pertumbuhan rambut, menebalkan epidermis dan memulihkan pertumbuhannya, dimana epidermis yang menipis secara alami seiring dengan proses penuaan akan memicu terjadinya kerontokan. Pegagan dapat menyembuhkan peradangan sekitar folikel rambut, mengurangi efek hormon penyebab kerontokan yaitu Dyhidrotestosteron (DHT) secara signifikan. Mekanisme lainnya dari 
pegagan adalah dapat memperkuat pembuluh darah sehingga memperluas miniatur folikel, maka dengan demikian sistem sirkulasi ke folikel rambut membaik sehingga memungkinkan masuknya nutrisi dan oksigen ke dalam folikel rambut ( Bylka 2013; Thorat 2010).

\section{KESIMPULAN}

Kombinasi ekstrak air daun teh hijau dan ekstrak air herba pegagan mempunyai aktivitas sebagai penyubur rambut dan kombinasi ekstrak yang paling optimum adalah kombinasi 1 dengan konsentrasi ekstrak air daun teh hijau (5\%) dan ekstrak air herba pegagan $(2,5 \%)$ dengan laju pertumbuhan rambut $2,689 \mathrm{~cm}$ dalam 28 hari, percepatan pertumbuhan rambut $0,128 \mathrm{~cm} /$ hari dan bobot rambut 0,1938 gram dalam 28 hari.

\section{DAFTAR PUSTAKA}

Amin J., Simamora Esther Lamria Purba., Anwar E., Djajadisastra J, 2014. Green Tea (Camellia sinensis L) Ethanolic Extract As Hair Tonic In Nutraceutical; Physical Stability, Hair Growth Activity On Rats, And Safety Test, International Journal of Pharmacy and Pharmaceutical Sicences. 6 (5) : 94-99.

Bylka W., Znajdek-Awizen P., Studzinska - Sroka E., Brzenzinska M, 2013. Centella asiatica in Cosmetology, Postep Derm Alergol; XXX (1) : 46-49.

Esfandiari A., Kelley P, 2005 . The Effect Tea Poliphenolic Compounds on Hair Loss Among Rodents, Journal Of The National Mediccal Association. 97 (6) : 816-818.

Harrison S., Bergfeld W., 2009. Diffuse Hair Loss: Its Triggers and Management, Ceveland Clinic Journal of Medicine. 76 (6) : 361-367.

Jain R., Jain K. N., Singh N., Gnanachandran A K, Glokulan P.D, 2011. Development and Evaluation of Polyherbal Ointment For Hair Growth Activity,International Journal of Pharmacy and Pharmaceutical Science. 3 (2): 180-182.

Longo G., Karan M., Sharma P.D., Rakesh D.D., Vyas S., Vasisht. K. 2008. Quantitative Analysis Of Green Tea Polyphenosin Indian Cultivars, in Jain N.K., Rahman F.,Baker P., Economic Crisis in Tea Industry. Studium Press LLC. Hauston USA. 275-282.

Purwantini I., Munawaroh R.,Darwati N.,B.S. 2008.Combination Of The And Mangkokan Leaves Extract To Promote Hair Growth, Traditional Medicine Journal $13: 43$.

Priskila V., 2012. Uji Stabilitas Fisik dan Uji Aktivitas Pertumbuhan Rambut Tikus Putih Jantan dari Sediaan Hair Tonik Yang Mengandung Ekstrak Air Bonggol Pisang Kepok (Musa balbisiana).(Skripsi) Depok Fakultas Farmasi Universitas Indonesia.28-30.

Sharma A K., Agarwal V., Kumar R., Kaushik K., Bharwadj P. 2010. Development And Evaluation Of Herbal Formulation For Hair Growth, Inter J Curr Trends Sci Tech, 1 (3) : 147-151.

Sandeep K., Nisha S., Shweta., Archana. 2012. Green Tea Polyphenols : Versatile Cosmetic Ingredient, International Journal Of Advanced Research In Pharmaceutical \& Bio Sciences. 1 (3) : 348-362.

Thorat R.M , 2010. Herbal Treatment For Hair Loss, International Journal of Pharmacy \& Technology.2 (4) : 497-503.

Zheng Cheng-jian., QIN Lu-ping, 2007. Chemical Components of Centella asiatica and their Bioactivities, Journal of Chinese Integrative Medicine, 5 (3) : 348-351. 